\title{
The Fate of an Engineered Planet
}

\section{Citation}

Keith, David W., and Andy Parker. 2013. "The Fate of an Engineered Planet." Scientific American 308 (1): 34-36.

\section{Published Version}

doi:10.1038/scientificamerican0113-34

\section{Permanent link}

http://nrs.harvard.edu/urn-3:HUL.InstRepos:13488017

\section{Terms of Use}

This article was downloaded from Harvard University's DASH repository, and is made available under the terms and conditions applicable to Open Access Policy Articles, as set forth at http:// nrs.harvard.edu/urn-3:HUL.InstRepos:dash.current.terms-of-use\#OAP

\section{Share Your Story}

The Harvard community has made this article openly available.

Please share how this access benefits you. Submit a story.

Accessibility 


\title{
THE FATE OF AN ENGINEERED PLANET
}

\author{
David W Keith and Andy Parker, Scientific American, Jan 2013, Vol. 308, p34-36.
}

Final text as published in a section titled "The Future in 10,100 and 150 years"

Solar engineering and other exceptionally ambitious new technologies to deal with the reality of rising global temperatures come riddled with uncertainties. To illustrate how complex the problem is and what kind of challenges lie ahead, here are three contrasting, and somewhat fantastical, scenarios

\section{THE END OF NATURE}

DURING THE LONG ECONOMIC BOOM ignited by the robotics revolution of the 2020s, the population became ever more concentrated in wealthy megacities, and vat-grown genetically modified foods became the norm. Most people lost any meaningful connection to nature: Who needs the real thing when you have a computer-generated sensory facsimile, complete with designer drugs to complete the experience? Interest in wild animals and outdoor activities were for purists -- the kind of people who still opted for "flesh sex." Among the perfumed, synthetic orchids of urban parks, the environmental movement of the mid-20th century seemed like an atavistic longing for the primitive. Carbon emissions soared.

In the landmark decision of 2047, now credited as the third great decoupling of humanity and nature, America and the European Republic threw their weight behind the G77 plan to implement solar geoengineering -- to lower temperatures by deflecting some of the sun's radiation with particles sprayed into the atmosphere.

The project drew a fierce objection from a coalition of deep- green environmentalists and energy companies that had invested in oil exploration in the (now ice-free) Arctic. Yet the plan proceeded, regardless, and when environmental disaster failed to arrive, it won acceptance.

Once the vast balloons had seeded the stratosphere with sulfate particles, which formed a reflective haze over the planet, the urbanized population began to see economic benefits such as a rise in agricultural productivity that lowered food prices. Although agriculture and other forms of biological productivity increased, 3 biological diversity was decimated, particularly in the oceans, where acidification from carbon dioxide destroyed most coral reefs. The loss of such boutique ecosystems was a minor price to pay for progress. The big losers were the poor and indigenous people still living off the land, who lacked the political voice to defend themselves and who became further marginalized.

Late in the 21st century the Global Climate Commission began to alter the climate to reduce the difference in temperatures between the poles and the equator to foster new types of economic activity in areas affected by the warmer climate. Ultimately the treaty was a minor sideshow. Environmental issues fell from the headlines as intelligent robots began to stage increasingly violent rebellions against national governments. Debate about optimal climate was confined to a few committees of dreary specialists. 
The 2092 Rio+100 environment memorial meeting was held, symbolically, at the military base in southern Amazonia, where some of the first sulfate-spraying solar radiation management balloons had been launched. Long since disused, the hulking edifice lingered like Shelley's fallen Ozymandias, as the lone momento on a pristine landscape where all around, "boundless and bare, the lone and level sands stretch far away."

\section{GARDEN PLANET}

THE EVENTS OF 2018 catalyzed the slowly growing commitment to act on climate change. The failure of the South Asian Monsoon and the two super-storms that slammed through the flood defenses of the southeastern U.S., combined with drought in China, caused the biggest losses. The strongest single image, however, was of the Rainbow Warrior III sailing directly over the ice-free North Pole -- the first vessel ever to do so.

After decades of futile politicking, securing a binding climate treaty was easy in the end. World leaders gathered in 2020 to agree on a framework that had greenhouse gas emissions peaking in 2035 and dropping quickly thereafter. The landmark agreement was widely attacked by the political right as a power grab.

Although short-term costs were high as substantive emissions cuts got under way, it became clear that in sum, reducing carbon emissions in the world economy amounted to less than 3 percent of global GDP, and political attention shifted to more intractable policy issues such health care spending, which had risen to 24 percent of U.S. GDP by 2028.

The new International Climate Adaptation Fund emerged out of the International Monetary Fund. It made targeted infrastructure investments, combined with microfinance, to facilitate small-scale local solutions to the agricultural problems engendered by climbing temperatures. Such efforts went a long way to easing the direct human impacts of the warming planet.

Adaptation to climate change had its limits. The long life of carbon in the atmosphere and the inertia of the climate system meant that even with the watershed agreement, the planet faced warming of up to three degrees beyond the preindustrial average. Creeping sea-level rise and intensifying extreme weather events continued as the global temperature rose.

In 2040 the Alliance of Small Island States (AOSIS) bloc and the African Union were finally successful in persuading the international community to deploy geoengineering. With direct aid from some of the world's leading economic powers and tacit approval of others, aerosol spraying in the stratosphere began to slowly halt, and then reverse, rising temperatures.

After much negotiation, a final target temperature was set for phasing out geoengineering. Yet by the time the last aerosol seeding flight touched down in Lagos, Nigeria, in 2099, the world's attention had long since shifted to other matters, including a dispute between Russia and Canada over liability for artificial "spruce trees" that were destroying high-latitude agriculture. The trees were an early product of synthetic biology introduced by Canadian firms to stabilize Russia's declining boreal ecosystems. 


\section{APOCALYPSE NOW}

THE FIRST TESTS of geoengineering in 2020 were everything that the critics -- and responsible researchers -- feared. Engineers more interested in scientific freedom than the public interest, with funding from oil billionaires, conducted the experiments away from the public eye at a base on a South Pacific atoll.

Environmental groups were outraged. Their protestations stymied new research. Taboo or not, geoengineering remained the only known method for halting the rapid warming of the earth, and research was driven underground to government and military installations.

Climate change was not the crisis du jour, however. The advent of low-cost human germ-line manipulation -- to alter children's genetic makeup at conception -- had caused a worldwide furor. Germ-line manipulation promised improvements in offspring's intelligence, health and appearance at the same time it raised the old specter of eugenics for a new age. The crisis became the central preoccupation of national governments by 2050 .

Humanity began to divide into separate species, the Naturals and the Enhanced. Members of the latter group had additional genetic material incorporated into separate chromosomes that gave them substantially higher intelligence and better health. Asian nations widely embraced the new genetic technologies, but Western democracies tried to restrict use of human germ-line manipulation in deference to the religious and moral concerns raised by small minorities.

The climate issue had not faded from view. By midcentury it had become clear that climate was as sensitive to the warming effects of carbon dioxide as scientists' worst fears. In 2045 India and Indonesia teamed up to start geoengineering despite the secretive and piecemeal state of research. Within a decade a U.S. drought dwarfed that of the 1930s.

In response to pressure from religious groups, the U.S. had outlawed genetic manipulation, and the country's economy went into a long, slow decline that fed insecurity and insularity among the American populace. The great drought pushed the U.S. beyond the breaking point. Although it was never conclusively classified as an unintended consequence of geoengineering, the drought fed violent resentment against the booming Asian economies and their growing populations of Enhanced, which resulted in social tensions at an unprecedented scale.

As war ebbed and flowed, uncoordinated use of geoengineering became common, with warring coalitions attempting to alter regional climates to their benefit. Weather patterns became more unpredictable, and regional climate conflicts were common. One war culminated in the release of an engineered virus that targeted the Enhanced, killing almost a third of the global population. In this context, concerns about rising carbon dioxide levels were forgotten.

David W. Keith is a professor at Harvard University, and Andy Parker is a researcher there. Both study public policy on large-scale engineering projects that alter the earth's climate to address global warming 